\title{
Decoding the Clinical and Laboratory Parameters of COVID-19 and Dengue Co-infection
}

\author{
C.V. Swapnamanjari (D), Anusha Gopinathan* (iD) and K.V. Leela $(\mathbb{D}$ \\ Department of Microbiology, SRM Medical College Hospital and Research Centre, Faculty of Medicine and \\ Health Sciences, SRM Institute of Science and Technology, SRM Nagar, Kattankulathur - 603 203. Kanchipuram, \\ Chennai, Tamil Nadu, India.
}

\begin{abstract}
Severe acute respiratory diseases caused by coronavirus disease 2019 (COVID-19) have caused infections around the world, and this disease has been declared a global pandemic by the World Health Organization. COVID-19 has severely impacted the world economy, and as it has multiple unnoticeable transmission routes, it can derail the health care system for a long time. Most states in India are affected by the COVID pandemic. As India is known for its seasonal infections such as dengue, leptospirosis, influenza, malaria, and enteric fever, it is expected that these infections may co-exist. Coinfection of these two viral infections causes challenges in diagnosis and treatment, especially in places with limited resources. Antibody-mediated enhancement of the immune response is a cause for concern in co-infection of COVID-19 and dengue. The present article discusses the clinical features, serological cross reactions, and antibody-dependent enhancement of COVID-19 coinfection with dengue infection.
\end{abstract}

Keywords: acute respiratory syndrome, COVID-19, dengue, co-infection, symptoms, clinical feature, serological cross reaction, antibody dependent enhancement

(C) The Author(s) 2022. Open Access. This article is distributed under the terms of the Creative Commons Attribution 4.0 International License which permits unrestricted use, sharing, distribution, and reproduction in any medium, provided you give appropriate credit to the original author(s) and the source, provide a link to the Creative Commons license, and indicate if changes were made. 


\section{INTRODUCTION}

Coronavirus SARS-CoV-2 (COVID-19) is a respiratory disease that originated in December 2019 in the Wuhan district, Hubei Province, China. The disease was linked epidemiologically to a seafood market in the area which sold live animals. The etiological agent of COVID-19 was identified as SARS CoV2 in January 2020. The disease was declared a Public Emergency of International Concern on January 30, 2020, and was declared a global pandemic on March 11, 2020. As of September 25, 2021, India recorded a total of 300,000 active cases of COVID-19. The virus is spread through droplet transmission from symptomatic and asymptomatic patients with an incubation period of 2-14 days. ${ }^{3-5}$ Dengue is a disease which is commonly seen in tropical and subtropical regions and is caused by four serotypes of dengue virus. This disease is a public health problem similar to COVID-19 and is transmitted by the mosquito Aedes aegypti. Asian travellers are frequently afflicted by this infection. Dengue cases increased in most countries during the COVID-19 pandemic. Countries such as Brazil, Thailand, and Ecuador have reported the most cases of dengue during the ongoing SARS CoV2 pandemic. Dengue viral infections have also increased in places which have previously not reported a single case of dengue. As of July 2021, India recorded 14,000 cases of dengue viral infection..$^{7-9}$ Dengue is one of the leading causes of mosquito borne diseases in Southeast Asia.

The most common clinical symptoms of COVID-19 are fever, fatigue, rashes, petechiae, and muscle pain. This resembles most endemic viral infections, making diagnosis of COVID-19 challenging and difficult. The Ministry of Health and Family Welfare in India has alerted all medical institutions about possible dengue outbreaks during rainy and post rainy seasons in areas showing high prevalence of COVID-19 infection. Though COVID-19 and dengue viral infection are similar in their clinical manifestations and laboratory parameters, including thrombocytopenia and leukopenia, they differ in their management and treatment modalities. Reverse transcription-polymerase chain reaction (RT-PCR) and enzyme-linked immunoassay (ELISA) have become very important for differentiating between dengue and COVID-19 infection. ${ }^{12,13}$ The onset of the COVID-19 pandemic has caused fear in most countries regarding dengue outbreaks in their vulnerable population. Diagnosis and differentiation between the two diagnoses have been a challenge to the health system and have resulted in undue delay in treatment and implementation of isolation measures against both infections.

Demographic, clinical, and laboratory characteristics of COVID-19 and dengue viral co-infection

Indonesia has recorded the highest number of cases of dengue and COVID-19 coinfection, followed by Pakistan and India. The diagnostic tests used for diagnosis of dengue are RT-PCR, ELISA, and rapid serology kits, whereas RT-PCR and rapid diagnostic tests are used for COVID-19 diagnosis. Most co-infections have been seen in males and adults between the ages of 18-64 years. There has been a report of COVID-19 and dengue co-infection in a 6 year-old pediatric patient. The most common clinical features in patients with co-infection are fever, dyspnea, fatigue, headache, and cough. The other clinical manifestations are arthralgia, retro-orbital pain, photophobia, and anorexia.

The laboratory characteristics of COVID-19 with dengue co-infection are leukopenia, lymphopenia, thrombocytopenia, and elevated alanine transaminase levels. The other laboratory parameters seen in co-infection of these diseases are elevated $C$ reactive protein (CRP), elevated D-dimer, elevated erythrocyte sedimentation rate, reduced hematocrit, reduced hemoglobin, and leukocytosis. Chest X-ray and computed tomography in these patients show ground glass opacities in most cases, followed by bilateral lung opacity or lung infiltrate. The average number of days for recovery in patients is 9-20 days. Shock, acute respiratory distress syndrome, and multiple organ failure have been seen in a few cases of COVID-19 and dengue co-infection. ${ }^{14-18}$

\section{Similarities in the pathogenesis of COVID-19 and dengue viral infection}

There are numerous similarities in the pathogenesis of SARS CoV2 infection and dengue viral infection. Thrombocytopenia, coagulation cascade, and plasma leakage are seen in both 
disease conditions. Plasma leakage is an important component in the pathogenesis of dengue, and is caused by immune mediators such as tumor necrosis factor (TNF), interferon gamma (IFN- $\gamma$ ), interleukin 6 (IL-6), and chemokines such as macrophage inhibition factor. Plasma leakage is also caused by elevated C-reactive protein and platelet dysfunction. Thrombocytopenia is caused by numerous factors in dengue infection. First, it can be caused by the interaction between endothelial cell surface proteins and nonstructural protein-specific antibodies. Second, interaction of platelets with endothelium, leukocytes, and monocytes facilitated by higher expression of $E$ selectin and $P$ selectin on endothelial cells infected by dengue virus can also result in thrombocytopenia. Third, the immunoglobulins associated with platelets also play a role in the thrombocytopenia seen in dengue patients. ${ }^{19-28}$

In COVID-19, plasma leakage, vascular permeability, and disseminated intravascular coagulation are induced by overactivation of $\mathrm{T}$ cell function and immune mediators such as TNF, IFN- $\gamma$, IL-1, and IL-6, which are also responsible for the cytokine storm seen in this infection. ${ }^{20}$ Severity in COVID-19 is associated with increasing levels of CRP, which is produced by hepatocytes stimulated by inflammation. This in turn activates the classical complement pathway. The severity of COVID-19 infection is also associated with thrombocytopenia. COVID-19 causes endothelial cell damage, inhibits bone marrow growth, and induces apoptosis, which results in decreased hematopoiesis and thrombocytopenia. Autoimmune antibodies and immune complexes also facilitate destruction of platelets in COVID-19

Coagulopathy is seen in both dengue and COVID-19 infections. Prothrombin time and partial thromboplastin time are elevated in both conditions. Other coagulation factors, such as prothrombin, antithrombin, $\alpha 2$ antiplasmin, and factors II, V, VIII, IX and X, are not activated in dengue, but are activated in COVID-19. COVID-19 creates a hypercoagulable condition in the body and thus is associated with cerebrovascular accidents, stroke, myocardial infarction, and venous thromboembolism. Hepatic injuries due to immune mechanisms and direct cytotoxicity caused by replication of the virus in hepatic cells have also been documented in COVID-19. ${ }^{29-33}$
Antibody-dependent enhancement in COVID-19 and dengue viral infection

Antibody-dependent enhancement (ADE) is seen both in COVID-19 and dengue infection. The presence of cross-linkages between the virus and antibody or complement component complexes causes internalization of the virus and increases the infectivity of granulocytic and monocytic cells in dengue viral infection. Homotypic dengue infection results in long-lasting immunity, but the neutralizing antibodies against the various other serotypes of dengue are short-lived. The heterotypic antibodies can trigger ADE at subneutralizing concentrations during secondary infection and cause severe disease, especially in children. ${ }^{34-36}$

COVID-19 produces a cytokine storm which leads to rapid viral replication, cell damage, uncontrolled pulmonary inflammation, downregulation of angiotensin converting enzyme 2 , and ADE. Neutralizing antibodies against the spike protein produces a complex with SARS CoV2. The interaction between this complex and Fc receptors in the susceptible cells leads to ADE. This results in inflammation and replication of the virus in the lungs. COVID-19 is unique in that it does not utilize the lysosomal and endosomal pathways of ACE2 receptor for ADE. ${ }^{37-41}$

\section{Serological cross-reactions between COVID-19 and dengue viral infection}

It is extremely difficult to differentiate COVID-19 and dengue in the first 24-48 $\mathrm{h}$ after onset of symptoms. Rapid serology tests have a short turnaround time and help in timely diagnosis of COVID-19. Cross-reactions between COVID-19 and dengue viral infections have been reported in a few studies. A Columbian study reported a decrease in the incidence of dengue infection with the rapid increase in COVID-19 cases in their country. This indicates the futility of using rapid antibody tests, especially lateral flow immunoassays, as point-of-care testing for COVID-19. RT-PCR is vital for the confirmation of COVID-19 and dengue viral infection in tropical and subtropical countries. Special attention is required for the diagnosis of mixed infection of dengue and COVID-19 in countries with limited resources in Asia. ${ }^{42-43}$ 


\section{CONCLUSION}

It is a challenge to differentiate COVID-19 and dengue fever in places endemic to tropical arboviral infections due to the similarities in their clinical features and laboratory parameters. Serological cross reactions between the two infections cause undue delay in diagnosis and appropriate treatment. The need for RT-PCR to confirm the diagnosis of COVID-19 and dengue infections is paramount. COVID-19 and dengue viral co-infection can cause severe morbidity and mortality, and this article highlights the need for their accurate diagnosis and timely management.

\section{ACKNOWLEDGMENTS}

None.

\section{CONFLICT OF INTEREST}

The authors declare that there is no conflict of interest.

\section{AUTHORS' CONTRIBUTION}

All authors listed have made a substantial, direct and intellectual contribution to the work, and approved it for publication.

\section{FUNDING}

None.

\section{ETHICS STATEMENT}

Not applicable.

\section{DATA AVAILABILITY}

The data generated during and/or analysed during the current study are available from the corresponding author on reasonable request.

\section{REFERENCES}

1. Harapan $\mathrm{H}$, Itoh N, Yufika A, et al. Coronavirus disease 2019 (COVID-19): a literature review. J Infect Public Health. 2020;13(5):667-673. doi: 10.1016/j. jiph.2020.03.019

2. Rafiq D, Batool A, Bazaz MA. Three months of COVID-19: a systematic review and meta-analysis. Rev Med Virol. 2020;30(4):e2113. doi: 10.1002/rmv.2113

3. Singhal T. A review of coronavirus Disease-2019 (COVID). Indian J Pediatr. 2020;87(10223):281-286. doi: $10.1007 / \mathrm{s} 12098-020-03263-6$

4. Modes of transmission of virus causing COVID-19: implications for IPC precaution recommendations. World Health Organization. Newsroom. Commentaries.
2020. https://www.who.int/news-room/ commentaries/detail/modes-of-transmission-of-viruscausing-covid-19-implications-for-ipc-precautionrecommendations. Accessed 1 October, 2021.

5. Saha A, Saha B. Novel coronavirus SARS-CoV-2 (COVID-19) dynamics inside the human body. Rev Med Virol. 2020;30(5):e2140. doi: 10.1002/rmv.2140

6. World Health Organization. Coronavirus disease 2019 (COVID-19), weekly epidemiological update, edition 45. 2021. https://www.who.int/publications/m/item/ weekly-epidemiological-update-on-covid-19---22june-2021 Accessed on June28th, 2021

7. Lorenz C, Azevedo TS, Chiaravalloti-Neto F. COVID-19 and dengue fever: a dangerous combination for the health system in Brazil. Travel Med Infect Dis. 2020;35:101659. doi: 10.1016/j.tmaid.2020.101659

8. News Desk. Thailand dengue cases top 60,000; Mae Hong Son province reports highest prevalence. Outbreak News Today. 2020. https:// outbreaknewstoday.com/thailand-dengue-casestop-60000-mae-hong-son-province-reports-highestprevalence-69877/. Accessed on 20 September, 2021.

9. Navarro JC, Arrivillaga-Henriquez J, Salazar-Loor J, Rodriguez-Morales AJ. COVID-19 and dengue, coepidemics in Ecuador and other countries in Latin America: pushing strained health care systems over the edge. Travel Med Infect Dis. 2020;37:101656. doi: 10.1016/j.tmaid.2020.101656

10. National Vector Borne Disease Control Programme. Dengue situation in India. https://nvbdcp.gov.in/ index4.php?lang=1\&level $=0$ \&linkid $=431$ \&lid $=3715$ Accessed date: October 2nd, 2021

11. Guidelines for management of co-infection of COVID-19 with other seasonal epidemic prone diseases. Ministry of Health \& Family Welfare. Directorate General of Health Services. India. https:// www.mohfw.gov.in/ Accessed on 21 September 2021.

12. Verduyn M, Allou N, Gazaille V, et al. Coinfection of dengue and COVID-19: a case report. PLoS Negl Trop Dis. 2020;14(8):e0008476. doi: 10.1371/journal. pntd.0008476

13. Epelboin L, Blonde R, Nacher $\mathrm{M}$, Combe $\mathrm{P}$, Collet $\mathrm{L}$. COVID-19 and dengue co-infection in a returning traveller. J Travel Med. 2020;27(6):taaa114. doi: 10.1093/jtm/taaa114

14. Bicudo N, Bicudo E, Costa JD, Castro JALP, Barra GB. Co-infection of SARSCOV-2 and dengue virus: a clinical challenge. Braz J Infect Dis. 2020;24(5):452-454. doi: 10.1016/j.bjid.2020.07.008

15. Somasetia DH, Malahayati TT, Andriyani FM, Setiabudi D, Nataprawira HM. A fatal course of multiple inflammatory syndrome in children coinfection with dengue. A case report from Indonesia. ID Cases. 2020;22:e01002. doi: 10.1016/j.idcr.2020.e01002

16. Ratnarathon AC, Pongpirul K, Pongpirul WA, Charoenpong L, Prasithsirikul W. Potential dual dengue and SARS-CoV-2 infection in Thailand: A casestudy. Heliyon. 2020;6(6):E04175. doi: 10.1016/j. heliyon.2020.e04175

17. Radisic MV, Piro MA, Mori I, Rotryng F, Santamarina JF. SARS-CoV-2 and dengue virus co-infection. A case report. Infezioni in Medicina. 2020;28(3):416-419. 
18. Masyeni S, Santoso MS, Widyaningsih PD, et al. Serological cross-reaction and coinfection of dengue and COVID-19 in Asia: Experience from Indonesia. Int J Infect Dis. 2021;102:P152-154. doi: 10.1016/j. ijid.2020.10.043

19. Schexneider K, Reedy E. Thrombocytopenia in dengue fever. Curr Hematol Rep. 2005;4:145-148.

20. Kalayanarooj S, Chansiriwongs V, Nimmannitya S. Dengue patients at the Children's Hospital, Bangkok: 1995-1999 Review. 2002. https://apps.who.int/iris/ handle/10665/163764 Accessed on July 25th, 2021

21. Mourao MPG, Lacerda MVG, Macedo VO, et al. Thrombocytopenia in patients with dengue virus infection in the Brazilian Amazon. Platelets. 2007;18(8):605-612. doi: 10.1080/09537100701426604

22. Bozza FA, Cruz OG, Zagne SM, et al. Multiplex cytokine profile from dengue patients: MIP-1beta and IFNgamma as predictive factors for severity. BMC Infect Dis. 2008;8:86. doi: 10.1186/1471-2334-8-86

23. Honda S, Saito M, Dimaano EM, et al. Increased phagocytosis of platelets from patients with secondary dengue virus infection by human macrophages. $\mathrm{Am}$ J Trop Med Hyg. 2009;80(5):841-845. doi: 10.4269/ ajtmh.2009.80.841

24. Hottz E, Tolley ND, Zimmerman GA, Weyrich AS, Bozza FA. Platelets in dengue infection. Drug Discov Today:Dis Mech. 2011;8(1-2):e33-e38. doi: 10.1016/j. ddmec.2011.09.001

25. Lin $Y-S$, Yeh T-M, Lin C-F, et al. Molecular mimicry between virus and host and its implications for dengue disease pathogenesis. Exp Biol Med. 2011;236:515523. doi: 10.1258/ebm.2011.010339

26. Krishnamurti C, Peat RA, Cutting MA, Rothwell SW. Platelet adhesion to dengue-2 virus-infected endothelial cells. Am J Trop Med Hyg. 2002;66(4):435441. doi: 10.4269/ajtmh.2002.66.435

27. Ghosh K, Gangodkar S, Jain P, et al. Imaging the interaction between dengue 2 virus and human blood platelets using atomic force and electron microscopy. J Electron Microsc. 2008;57(3):113-118. doi: 10.1093/ jmicro/dfn007

28. Tsai J-J, Jen Y-H, Chang J-S, Hsiao HM, Noisakran S, Perng GC. Frequency alterations in key innate immune cell components in the peripheral blood of dengue patients detected by FACS analysis. I Innate Immun. 2011;3:530-540. doi: 10.1159/000322904

29. Lippi G, Plebani M, Henry BM. Thrombocytopenia is associated with severe coronavirus disease 2019 (COVID-19) infections: a meta-analysis. Clin Chim Acta. 2020;506:145-148. doi: 10.1016/j.cca.2020.03.022

30. Yang $X$, Yang $Q$, Wang $Y$, et al. Thrombocytopenia and its association with mortality in patients with COVID-19. J Thromb Haemost. 2020;18(6):1469-1472. doi: $10.1111 /$ jth.14848
31. Rodriguez-Morales AJ, Cardona-Ospina JA, GutierrezOcampo $E$, et al. Clinical, laboratory and imaging features of COVID-19: a systematic review and metaanalysis. Travel Med Infect Dis. 2020;34:101623. doi: 10.1016/j.tmaid.2020.101623

32. Zhang $\mathrm{Y}$, Zeng $\mathrm{X}$, Jiao $\mathrm{Y}$, et al. Mechanisms involved in the development of thrombocytopenia in patients with COVID-19. Thrombosis Research. 2020;193:110-115. doi: 10.1016/j.thromres.2020.06.008

33. Xu P, Zhou Q, Xu J. Mechanism of thrombocytopenia in COVID-19 patients. Ann Hematol. 2020;99(6):12051208. doi: 10.1007/s00277-020-04019-0

34. Tirado SM, Yoon KJ. Antibody-dependent enhancement of virus infection and disease. Viral Immunol. 2003;16(1):69-86. doi: 10.1089/088282403763635465

35. Huisman W, Martina BEE, Rimmelzwaan GF, Gruters RA, Osterhaus ADME. Vaccine-induced enhancement of viral infections. Vaccine. 2009;27(4):505-512. doi: 10.1016/j.vaccine.2008.10.087

36. Khandia R, Munjal A, Dhama K, et al. Modulation of dengue/Zikavirus pathogenicity by antibodydependent enhancement and strategies to protect against enhancement in Zika virus infection. Front Immunol. 2018;9:597. doi: 10.3389/fimmu.2018.00597

37. Jin $\mathrm{Y}$, Yang $\mathrm{H}$, Ji W, et al. Virology, epidemiology, pathogenesis, and control of COVID-19. Viruses. 2020;12(4):372. doi: 10.3390/v12040372

38. Dhama K, Patel SK, Pathak M, et al. An update on SARS-CoV- 2/COVID-19 with particular reference to its clinical pathology, pathogenesis,immunopathology and mitigation strategies. Travel Med Infect Dis. 2020;37:101755. doi: 10.1016/j.tmaid.2020.101755

39. Fu Y, Cheng $\mathrm{Y}, \mathrm{Wu} \mathrm{Y}$. Understanding SARS-CoV-2mediated inflammatory responses: from mechanisms to potential therapeutic tools. Virol Sin. 2020;35(3):266271. doi: 10.1007/s12250-020-00207-4

40. Wang S-F, Tseng S-P, Yen C-H, et al. Antibody-dependent SARS coronavirus infection is mediated by antibodies against spike proteins. Biochem Biophys Res Commun. 2014;451(2):208-214. doi: 10.1016/j.bbrc.2014.07.090

41. Kam YW, Kien F, Roberts A, et al. Antibodies against trimeric $S$ glycoprotein protect hamsters against SARS-CoV challenge despite their capacity to mediate FcgammaRII-dependent entry into B cells in vitro. Vaccine. 2007;25(4):729-740. doi: 10.1016/j. vaccine.2006.08.011

42. Tsheten T, Clements ACA, Gray DJ, Adhikary RK, Wangdi K. Clinical features and outcomes of COVID-19 and dengue co-infection: a systematic review. BMC Infect Dis. 2021;21(1):729. doi: 10.1186/s12879-021-064099

43. Harapan H, Ryan M, Yohan B, et al. Covid-19 and dengue: Double punches for dengue-endemic countries in Asia. Rev Med Virol. 2021;31(2):e2161. doi: 10.1002/rmv.2161 